\title{
Study on the Philosophical Reflection of the Ideological and Political Education
}

\author{
Juan Liü, a \\ ${ }^{1}$ Zhengzhou University of Industrial Technology, Xinzheng, Henan, China, 451100 \\ ${ }^{a}$ email
}

Keywords: Ideological and Political Education, Philosophical Reflection, Marxism

\begin{abstract}
In the context of philosophy in the ideological and political theory and practice of systematic combing, after the possibility of ideological and political education and philosophy certainly meet the multidimensional dimension of the Practice of Cultural Implications of Chinese Philosophy and profound Marxist ideology as a base of political education and philosophy meet. On this basis, this paper is to achieve the uncovering of the ideological and political education of basic philosophical content system. Through the ideological and political education theory foundation of human nature, the situation of human nature and ontological meaning, explain features, opened the ontological ideological and political education provision. Through ideological and political education carding cognitive content and logical architecture, clarified Epistemology constitutes ideological and political education; by the basic principles of ideological and political education "apartment manager to do", "Guan know in truth", "border management isomorphic", "Li reunification", "emotion in the truth" and "Physical and chemical row" thorough analysis to achieve the theoretical expression of the ideological and political education methodology like state.
\end{abstract}

\section{Introduction}

Ideological and political education is a certain social or community clusters with certain moral and political views of the members of society, and so certain ideas of educational activities. Its purpose is to make people who have become the ideal personality. All ideological and political education is not a political education, but also all the non-ideological education. As the name suggests, the ideological and political education is the integration of education in ideological education and political education (or a fusion or superposition). As said above, the relationship between ideological and political education and philosophy is individual, specific relationship with the general and abstract, they are fundamental "heterogeneity." Ideological and political education is at a specific time and space situation, in practice, the convention, it has experienced from "political work"-"ideological and political work" shift-"political and ideological work", and ultimately the formation of "ideological and political education" of the term. "Ideological Political Education" as the party and government, but also become a theoretical discipline. ("The ideological and political education" and therefore has two meanings, as the party and government to work as a practice behavior; discipline as a form of theoretical research when we are not specifically described, according to the context of [context] to be distinguished.) Theory it interdisciplinary research becomes the people's ideological and moral occurred, the internal and external environment, purpose, value, structure, dominant, procedures, management formed the law. The philosophy is based on the objective world as the object of study and investigation, in order to follow the laws of the objective world and the subjective world as the basis, to meet the purpose of the activities of people. However, from the aspect of the object of study, research, and academic subject characteristics and properties of two different research purposes and other subjects, how to meet, how might this encounter, how can it? Ideological and political education and fundamental philosophy of "heterogeneity", does not mean that the two "never in contact" does not mean that there is no link between the two. In other words, the two can meet, usually resides among the individual, the individual can not be separated between the general, both of you have me, I have you. Philosophy of subject-specific source of ideas, the specific subject again as the guiding philosophy 
of the ideological and political education to their way of thinking philosophical reflection, which is the specific requirements of ideological and political education, but also the philosophy of their own requirements, because philosophy as thought weapons, must also be to achieve the transformation of the world through concrete science.

Ideological and political education is an educational work, the educator must be educated and to have a certain philosophy of quality, any ideological and political education professors and researchers should be in research and learning must be based on certain philosophical views basic guidance. They must be based on certain philosophical basis, in accordance with the requirements of a certain philosophy and ideas to resolve the ideological and political education among the concrete and practical problems. Something very philosophical connotation of the world and life and so on ideological and political education work involved, is an integral part of the ideological and political education. In this respect, philosophy to develop, we need to be widely used in ideological and political education, and vigorously expand. As Lenin said: "Philosophy has no right of individual existence, its material is distributed in the middle of the demonstration can continue various sectors." Philosophy can be sustained development, it relied upon its deeply rooted in the middle of the doors of specific scientific, no matter what form of conduct, or to philosophy remains the gates based on specific scientific basis. Only on the basis of the doors on the specific science, philosophy will have an incentive for sustainable development. Philosophy is the most abstract and very general discipline, if lost or ignored the doors of their specific scientific achievements, philosophy becomes a "source of water" and "without trees." However, not only from a specific philosophy of science, nature, society and thinking all fields of science summary and conclusion, but it does not stop there, it will come back specific scientific, specific scientific guidance, and promote the development of specific scientific, this is the essence of philosophical development requirements. In short, the combination of philosophical and ideological and political education, but of philosophy itself demands. Ideological and political education is the role of philosophy "positions."

\section{Basic Dimension of Philosophy Ideological and Political Education}

Ideological and political education has a rich philosophical heritage, philosophical connotation detailed and rigorous logic system. Ontology ideological and political education, epistemology, methodology, theory of value, teleology and the carrier are rich on very deep philosophical meaning, which together constitute the basic philosophical content system of ideological and political education.

Marxist philosophy is not to "Mina fat owl" gesture launch, but in the first strong note, "Gallic rooster" sing times and shook the world; the purpose of Marxist philosophy is not only to "interpret the world "but to" change the world "for its ultimate concern. In the "material abundance and spiritual poverty" of the times, people are struggling in the short life of the city in pursuit of material, lack long-term vision and ultimate care, spiritual "desertification" trend is inevitable. However, people need a little spirit, not the spirit of the flesh as good as dead. How much we need the spirit of the desert spirit rain! Spiritual desertification way of governance depends on ideological and political education to the people's ideological and moral qualities to boot; depends on the philosophy of the people to enhance the spiritual realm.

Epistemology (Epistemology) is to explore the nature of human cognition, structure, understanding the relationship between objective reality and recognize the prerequisite and basis for understanding occurs, philosophical doctrines process and development of the law, understanding of issues such as the criterion of truth. Therefore, it is also known as "Theory of Knowledge." Our ideological and political education epistemology today by the world, life and values constituted. The main work of ideological and political education is moral education and political guidance. It lies in helping people through education to form a correct outlook on life and values, and then continue to push forward the socialist construction and development.

Duty of ideological and political education is "education", that ideological and political qualities and moral qualities of personality. Through the promotion of ideological and cultural quality of the 
people, improve people's mode of thinking and methods, new ideas of thinking people, thereby affecting people's behavior patterns. To achieve this effect, we need to have the right approach. "In the exploration of knowledge, the method of tool also is some means of subjective aspects of subjective aspects and objects by means of this relationship." The method in people understand and transform the world in the process, connecting the subject and object, play an important role.

Duty of ideological and political education is "education", that ideological and political qualities and moral qualities of personality. Through the promotion of ideological and cultural quality of the people, improve people's mode of thinking and methods, new ideas of thinking people, thereby affecting people's behavior patterns. To achieve this effect, we need to have the right approach. "In the exploration of knowledge, the method of tool also is some means of subjective aspects of subjective aspects and objects by means of this relationship." The method is in people understand and transform the world in the process, connecting the subject and object, play an important role. And to make this work smoothly implemented and achieved good results, you must follow a few basic principles: "apartment manager to do", "Guan know in truth", "border management isomorphic", "Li reunification" "emotion in the truth" and "physical and Chemical row." Only in this way, educators can clear the truth, the truth will be educated to understand.

\section{The Practical Significance of Political Philosophy Education}

Ideological and political education is a special "education" to work on the quality of people's overall shape and has an important role in the healthy growth of the educated. And it has been able to produce a significant impact on the educated, in its first follow the human nature of the activities. The influence of ideological and political education on people's behavior direction is much important.

Ideological and political education as a social phenomenon, and certainly other social phenomena (eg economic, political, cultural, ecological, etc.) linked, thus highlighting the specific value (such as economic value, political value, cultural value and ecological value, etc.) . Ideological and political education conforms to the development trend of history, for the smooth progress of the cause of socialism provides an ideological guarantee and intellectual support.

In short, through ideological and political education, comprehensively promote the political, economic, cultural and ecological harmony, to continue moving forward together for the construction of a harmonious society.

\section{Conclusion}

This article is based on the philosophy of sight to a theoretical reflection on the ideological and political education. First, the full text of ideological education and political philosophy encounter problems conducted a preliminary account of the main answer to both meet Possible problems and to learn from the standpoint of the occurrence of the two encounters were investigated; then focuses on the basic philosophy of the ideological and political education content system, mainly to sort out from ontology, epistemology and methodology of the three parts of its content; the last part of the article briefly places clear of ideological and political education significance of philosophical reflection.

\section{Acknowledgements}

Fund Project: 2016 Annual Henan Province Soft Science Research Project "Basis and Logic of Social Research Network Survivability College Student Group Ideology" (162400410535).

\section{References}

[1] Lu Jie. person to person to understand: Basic Moral Education-Reflections on the Contemporary Moral Education Transformation [J] "education" 2000.07. 
[2] Qi Wanxue, Tang Hanwei. People-centered and student-centered ethics and moral education [J]. "China Education" 2003. 01.

[3] Chen Binggong. "People-oriented" interpretation of moral ontology [J]. "Ideological education" 2004.11

[4] Wang Bei. Return to the Life Moral Knowledge Moral Education-Modern Moral Dilemma study [J] "Modern Education Science", 2010.4. 